\title{
Isolation and identification of bacterial flora from respiratory tract of healthy horses
}

\author{
Z. B. Muktha*, S. M. L. Kabir and M. T. Rahman \\ Department of Microbiology and Hygiene, Bangladesh Agricultural University, Mymensingh-2202, Bangladesh \\ *E-mail:zohura.muktha@gmail.com
}

\begin{abstract}
This study was carried out during the period of July to December, 2014 in order to isolate and characterize bacterial flora present in the respiratory tract of healthy horses in and around BAU campus. Eighteen apparently healthy horses were used for the study. Swab samples were collected from the nasal cavity. The bacteria was isolated ,identified and characterized by cultural (aerobic condition), staining, biochemical and PCR technique. Each of the samples collected yielded at least one bacterial species. A total of 27 bacteria were isolated from the selected animals. The majority of the isolates $(15 / 27,55.56 \%)$ were Gram-positive and the rest $(12 / 27,44.44 \%)$ were Gramnegative. Bacterial isolates were Staphylococcus aureus (83.33\%) and E. coli (66.66\%). The antimicrobial susceptibility pattern of bacterial isolates was investigated by disc diffusion method. The antibiotic sensitivity test of Staphylococcus aureus revealed that the isolates were highly sensitive to ciprofloxacin, moderately sensitive to gentamicin and resistance to amoxicilin, ampicilin and erythromycin. On the other hand, E. coli showed moderately sensitive to ciprofloxacin and gentamycin, mildly sensitive to erythromycin and resistance to amoxicilin and ampicilin. Detection of $E$. coli and S. aureus from the respiratory tract of healthy horses were not unexpected. Ciprofloxacin and gentamicin could be used for therapeutic purpose, if diseases occur by these organisms in horses.
\end{abstract}

Keywords: Isolation, Identification, Bacterial flora

\section{Introduction}

The common history of humans and horses date at about 3500 B.C. The archeological vestiges show that horses were used in welfare. Over time, horses have been gradually used in working, sports and leisure activities (Kristie Brookes 2011). It's true that in Bangladesh horse play a little in the economy. Horses are not available everywhere. Yet they are costly. So people of Bangladesh could not use them for the purpose of agriculture. Its seems that horses are somehow neglected. But, it is a matter of hope that, with the pace of modern world the people of Bangladesh are being more conscious about horse. As horses draw attention, the importance of horse increases gradually. Now, horse is used in recreational purpose such as in zoo, circus, horse race etc. As importance of horse increased day by day the question of health and hygiene will draw attention. But in our country there are many barriers exist in horse production. Among all problems respiratory problems are predominant. In every year a large number of horse populations die due to respiratory problem at the early stage of their lives. Pneumonia sometimes called strangle is one of the most common problems encountered in horse today. In horse stable pneumonia increases production costs associated with expensive treatments. Early diagnosis and proper treatment are essential for the effective treatment and prevention and control of the diseases. Respiratory diseases can be viral, bacterial, immune mediated (allergies), or mechanical in nature. They can be transient or chronic, serious or inconsequential. While some diseases can affect both the entire respiratory system, most are categorized as either upper airway disorders or lower airway disorders. Disorders of the upper airways are generally mechanical in nature while those of the lower airway are often the result of infection (Allen et al.,2006 ). Any horse can develop airway inflammation that can progress to serious disease over time. While it is always essential to watch horse for subtle signs of illness, it is also important to understand that significant airway disease may be present long before obvious symptoms occur. A study of horses of all ages although they appeared perfectly healthy, were performing well, and had no outward signs of lung problems revealed microscopic evidence of inflammatory airway disease (Gerber et al., 2003). This suggests that any horse can develop respiratory problems. Housing, feed, bedding, weather, and activity are all factors that influence the risk for any individual horse. Horses involved in high-intensity activities are particularly susceptible, especially if they live, train, or work in cold-weather conditions. Cold weather itself may be a significant problem for many horses. Exercising in frigid temperatures has been shown to cause inflammation in the lungs and 
airways, and may be a large factor in the development of respiratory infections and asthma (Davis et al., 2005). Signs of respiratory problems include poor performance, tiring more easily, taking longer for breathing to return to normal after exercise, increased breathing rate or effort, increased nasal mucus, increased snorting, coughing, and wheezing. It's worth noting that every exposure to the allergen causes inflammation that lasts for days, so horses that are outside during the day and only exposed to dust and allergens in the stable at night or in the arena are still at risk (Davis et al., 2007). Though viral, fungal and other causal agents responsible for respiratory problem, the present study was aimed at to focus only bacterial causes. Horse respiratory bacteria are ubiquitous in nature and are normal inhabitants of the respiratory tract of horse. This often creates difficulty in interpreting microbiological findings during an outbreak of respiratory diseases. Considering the above mentioned scenarios present study was carried out with the objectives (a) To determine the prevalence of bacterial flora found in respiratory tract of healthy horse based on their isolation and identification and (b) To determine the antibiogram of the isolated bacterial flora.

\section{Materials and Methods}

The experimental work was divided into three steps. The first step included selection of sources, collection of samples, isolation, identification and characterization of respiratory bacterial flora on the basis of their colony morphology, staining property, biochemical and PCR characteristics. The second step included determination of prevalence of isolated bacterial flora. The third step included the current status of drug sensitivity and resistance pattern of isolates of respiratory bacterial flora from nasal swab of healthy horses. The research work was conducted in the Department of Microbiology \& Hygiene, Bangladesh Agricultural University (BAU), Mymensingh-2202, during the period of July 2014 to December 2014. A total of 18 apparently healthy horses from different area of Mymensingh were selected for collection of nasal swab sample. All samples were collected directly from the respiratory system (nasal swab) of healthy horse into nutrient broth aseptically. The samples were carried to the laboratory in an ice box contained ice and processed for the isolation and characterization of bacteria subsequently.

\section{Bacteriological media for culture}

Commercially available synthetic media used in this experiment for bacteriological analysis were Blood agar (BA), Nutrient agar (NA), Mannitol salt agar (MS), Eosin Methylene Blue agar (EMB), SalmonellaShigella agar (SSA) etc. The following liquid media used for the study were Nutrient broth (NB), MethylRed and Voges -Proskauer broth (MR-VP broth) and different Sugar Media (dextrose, maltose, lactose, sucrose and mannitol).

\section{Sugars and reagents for biochemical tests}

Dextrose (LOBA Chemic Pvt. Ltd., India), Sucrose (Wako, Japan), Lactose (Merc, England), Maltose (Techno Pharma., India), Mannitol (Beximco Pharma., Germany), Methyl Red and Voges-Proskauer broth (MR-VP broth) (Difco, USA), Peptone water and Phosphate buffer solution were used. A commercial PCR master mix (2X master mix, Promega, U.S.A) was used to detect E. coli molecularly.

\section{Antibiotic sensitivity disc}

To perform this test, two types of bacteria isolated in this study were tested individually against 5 antibiotics. (ciprofloxacin, gentamycin, erythromycin, amoxycilin, ampicilin) based on common usefulness for the therapeutic purpose in the field and on the spectrum of their activity to determine the degree of antibiotic sensitivity to each of bacteria.

Gram's staining: Gram's staining was done as per the methods described by Merchant and Packer (1967) to determine the morphological features of bacteria.

Biochemical test: The carbohydrate fermentation test was carried out using suspected two isolates by inoculating a loop full of nutrient broth culture of the organisms into the tubes containing five basic sugars e.g., galactose, maltose, sucrose, mannitol,and glucose and incubated at $37^{\circ} \mathrm{C}$ for $24 \mathrm{hrs}$. Acid production was indicated by change of color from reddish to yellow in the medium (Jaswinder et al., 2004; Sameera et a1., 2001;Blackall, 1989; Hinz and Kunjara, 1977). 
Indole test Two $\mathrm{ml}$ of peptone water was inoculated with five $\mathrm{ml}$ of bacterial culture and incubated at $37^{\circ} \mathrm{C}$ for $48 \mathrm{hrs}$.Kovac's reagent $0.5 \mathrm{ml}$ was added, mixed well and examined after one min. Positive test was indicated by the development of red color (Jaswinder et al., 2004; Sameera et al., 2001).

Methyl-Red and Voges-Proskauer (MR-VR) test:These two tests were carried out following the routine procedures as described by others (Jaswinder et al., 2004; Sameera et al., 2001).

Catalase test : One $\mathrm{ml}$ of $3 \% \mathrm{H}_{2} \mathrm{O}_{2}$ was run down the slope and examined immediately and after 5 mins for the evaluation of gas production. Positive test indicated by the production of bubbles (Cheesbrough, 1985; Carter, 1979).

\section{Coagulase test:}

For the coagulase test, $0.5 \mathrm{ml}$ of rabbit plasma was diluted with sterile physiological saline (1:5) separately in two different test tubes containing an equal volume of 24 hours old isolated cultured broth and incubated at $37^{\circ} \mathrm{C}$ for 4 hours. The tubes were examined after 2-4 hours for detecting the presence of clots of plasma. The negative tubes were left at room temperature for over night and then re-examined. A simple slide coagulase test was also performed by mixing an equal volume of freshly cultured broth with rabbit plasma on a glass slide. A positive result was indicated by macroscopically clumping of the bacterial cells within five seconds because fibrinolysin enzyme lysis the rabbit plasma. Pathogenic Staphylococci showed coagulase-positive reaction whereas nonpathogenic Staphylococci showed negative result. In coagulase test, fibrinogen convert to fibrin and formation of clotting occur.

\section{DNA extraction}

A pure bacterial colony of $E$. coli from EMB agar was mixed with $200 \mu \mathrm{l}$ of deionized water which were boiled for 10 minutes then immediately kept on ice for cold shock for 10 minutes. Finally centrifugation was done at $10000 \mathrm{rpm}$ for 10 minutes. The supernatant were collected and used as DNA template for PCR. (Queipo-Ortun et al., 2008)

\section{Molecular detection of $E$. coli by PCR \\ Preparation of a PCR mixture \\ PCR mixture $(25 \mu \mathrm{l})$ was prepared as follows: \\ i) Nuclease free water $=5.5 \mu \mathrm{l}$ \\ ii) $2 X$ PCR master mixture (Promega, USA) $=12.5 \mu \mathrm{l}$ \\ iii) $\quad$ Forward primer $=1 \mu \mathrm{l}$ \\ iv) $\quad$ Reverse primer $=1 \mu \mathrm{l}$ \\ v) DNA template $=5 \mu \mathrm{l}$}

\section{PCR reaction profile}

PCR reaction profile was set as follows:

i) Initial denaturation $=95^{\circ} \mathrm{C}$ for $3 \mathrm{~min}$

ii) Denaturation $=94^{\circ} \mathrm{C}$ for $45 \mathrm{sec}$

iii) Annealing $=56^{\circ} \mathrm{C}$ for $45 \mathrm{sec}$

iv) Extension $=72^{\circ} \mathrm{C}$ for $1 \mathrm{~min}$

v) Final extension $=72^{\circ} \mathrm{C}$ for $3 \mathrm{~min}$

vi) Holding temperature $=4^{\circ} \mathrm{C}$ for $24 \mathrm{hrs}$

\section{Results and Discussion}

\section{Isolation and identification of bacteria}

Staphylococcus aureus: The samples were first inoculated on to Nutrient broth, after 24 hours incubation the colonies were subcultured on to nutrient agar and blood agar initially. The presence of gram positive cocci by Gram's stain and arranged in cluster form indicates Staphylococcus. The organism were sub-culture on MS media as selective media for Staphylococcus where it produces small colonies surrounded by yellow zones. On blood agar hemolysis was observed. On sugar fermentation test ferment five basic sugars and produce acid. Coagulase and Catalase test was positive. 
Escherichia coli: For the isolation and identification of coliform organism, the samples grown in nutrient broth were first inoculated into nutrient agar. The cultivated organism from nutrient agars were directly inoculated into EMB agar again. Metallic sheen on EMB agar were suspected as positive for E. coli and were confirmed by the IMViC utilization test (I=Indole, $M=$ Methylene-red, V=Voges-Proskauer, $\mathrm{C}=\mathrm{C}$ itrate). The E.coli was characterized by positive to indole and MR rest and negative to VP and Citrate test. On sugar fermentation test they produce both acid and gas.

Antibiotic sensitivity test : Antimicrobial drug susceptibility against five commonly used antibiotics were performed by disc diffusion or Kirby-Bauer method (Bauer et al. 1966). The zones of growth inhibition was compared with the zone-size interpretative table standard for E. coli and Staphylococcus spp. provided by Clinical and Laboratory Standards Institute (CLSI, 2007). The results of antibiotic sensitivity of $E$.coli revealed that highly sensitive to ciprofloxacin and gentamicin and moderately sensitive to erythromycin, resistance to amoxycilin, and ampicilin, and antibiotic sensitivity of Staphylococcus spp. revealed that highly sensitive to ciprofloxacin, moderately sensitive to gentamycin and resistant to amoxycilin, ampicilin and erythromycin. Antimicrobial testing results were recorded as resistant, intermediate and sensitive according to zone diameter interpretive standards provided by CLSI, (2007).

Table 1. Area wise prevalence of isolated bacteria

\begin{tabular}{l|c|c|c|c|c}
\hline $\begin{array}{l}\text { Name of } \\
\text { area }\end{array}$ & $\begin{array}{c}\text { Number } \\
\text { of } \\
\text { sample }\end{array}$ & $\begin{array}{c}\text { Number of sample } \\
\text { positive for } \\
\text { Staphylococcus aureus }\end{array}$ & $\begin{array}{c}\text { Number of sample } \\
\text { positive for } \\
\text { E.coli }\end{array}$ & $\begin{array}{c}\text { Prevalence } \\
\text { (\%) of Staphylococcus } \\
\text { aureus }\end{array}$ & $\begin{array}{c}\text { Prevalence } \\
\text { (\%) of } \\
\text { E.coli }\end{array}$ \\
\hline Sutiakhali & 7 & 5 & 4 & 71.43 & 57.14 \\
Muktagasa & 8 & 7 & 5 & 87.5 & 62.5 \\
BAU farm & 1 & 1 & 1 & 100 & 100 \\
BAU clinic & 2 & 2 & 2 & 100 & 100 \\
\hline
\end{tabular}

Table 2. Overall prevalence of isolated bacteria

\begin{tabular}{|l|c|c|}
\hline Isolated bacteria & No of sample examined & No of positive sample and percentage \\
\hline Escherichia coli & 18 & $12(66.66 \%)$ \\
\hline Staphylococcus aureus & 18 & $15(83.33 \%)$ \\
\hline
\end{tabular}

Table 3. Antimicrobial profile of Staphylococcus aureus and E. coli

\begin{tabular}{|c|c|c|c|c|c|c|c|c|c|c|}
\hline \multirow{3}{*}{$\begin{array}{c}\text { Sample } \\
\text { no. }\end{array}$} & \multirow{2}{*}{\multicolumn{2}{|c|}{ CIP(5 $\mu$ g/disc $)$}} & \multirow{2}{*}{\multicolumn{2}{|c|}{$\mathrm{E}(15 \mu \mathrm{g} / \mathrm{disc})$}} & \multicolumn{6}{|c|}{ LIST OF ANTIBIOTICS } \\
\hline & & & & & GEN(10 & g/disc) & $\operatorname{AMX}(10$ & Ig/disc) & AMP(10 & (disc) \\
\hline & S.aureus & E.coli & S.aureus & E.coli & S.aureus & E.coli & S.aureus & E.coli & S.aureus & E.coli \\
\hline 1 & $\mathrm{~S}$ & $\mathrm{~S}$ & $\mathrm{R}$ & I.S & $\mathrm{S}$ & $\mathrm{S}$ & $\mathrm{R}$ & $\mathrm{R}$ & $\mathrm{R}$ & $\mathrm{R}$ \\
\hline 2 & $\mathrm{~S}$ & $\mathrm{~S}$ & $\mathrm{R}$ & I.S & $\mathrm{S}$ & $\mathrm{S}$ & $\mathrm{R}$ & $\mathrm{R}$ & $\mathrm{R}$ & $\mathrm{R}$ \\
\hline 3 & $\mathrm{~S}$ & $\mathrm{~S}$ & $\mathrm{R}$ & I.S & $\mathrm{S}$ & $\mathrm{S}$ & $\mathrm{R}$ & $\mathrm{R}$ & $\mathrm{R}$ & $\mathrm{R}$ \\
\hline 4 & $\mathrm{~S}$ & $\mathrm{~S}$ & $\mathrm{R}$ & I.S & $\mathrm{S}$ & $\mathrm{S}$ & $\mathrm{R}$ & $\mathrm{R}$ & $\mathrm{R}$ & $\mathrm{R}$ \\
\hline 5 & $\mathrm{~S}$ & $\mathrm{~S}$ & $\mathrm{R}$ & I.S & $\mathrm{S}$ & $\mathrm{S}$ & $\mathrm{R}$ & $\mathrm{R}$ & $\mathrm{R}$ & $\mathrm{R}$ \\
\hline 6 & $S$ & $S$ & $\mathrm{R}$ & I.S & $S$ & $\mathrm{~S}$ & $\mathrm{R}$ & $\mathrm{R}$ & $\mathrm{R}$ & $\mathrm{R}$ \\
\hline 7 & $\mathrm{~S}$ & $\mathrm{~S}$ & $\mathrm{R}$ & I.S & $\mathrm{S}$ & $\mathrm{S}$ & $\mathrm{R}$ & $\mathrm{R}$ & $\mathrm{R}$ & $\mathrm{R}$ \\
\hline 8 & $\mathrm{~S}$ & $\mathrm{~S}$ & $\mathrm{R}$ & I.S & $\mathrm{S}$ & $\mathrm{S}$ & $\mathrm{R}$ & $\mathrm{R}$ & $\mathrm{R}$ & $\mathrm{R}$ \\
\hline 9 & $\mathrm{~S}$ & $\mathrm{~S}$ & $\mathrm{R}$ & I.S & $\mathrm{S}$ & $\mathrm{S}$ & $\mathrm{R}$ & $\mathrm{R}$ & $\mathrm{R}$ & $\mathrm{R}$ \\
\hline 10 & $\mathrm{~S}$ & $\mathrm{~S}$ & $\mathrm{R}$ & I.S & $\mathrm{S}$ & $\mathrm{S}$ & $\mathrm{R}$ & $\mathrm{R}$ & $\mathrm{R}$ & $\mathrm{R}$ \\
\hline
\end{tabular}

$\mathrm{CIP}=$ Ciprofloxacin, E=Erythromycin, GEN=Gentamicin, AMX=Amoxicilin, AMP=Ampicilin, R=Resistant, S=Sensitive, I=Intermediate 
The present study was conducted for the isolation, identification, and antibiotic sensitivity of the bacterial flora isolated from nasal swab of healthy horses in and around the BAU campus and Mymensingh. A total of 18 respiratory samples were collected for analysis. From the findings of the present study it may concluded that Staphylococcus aureus and E.coli were successfully isolated from the nasal swab of healthy horse. The prevalence of Gram positive bacteria was higher than Gram negative bacteria in respiratory tract of healthy horses. Staphylococcus aureus and E.coli both were sensitive to ciprofloxacin and gentamicin and resistance to ampicilin and amoxicilin

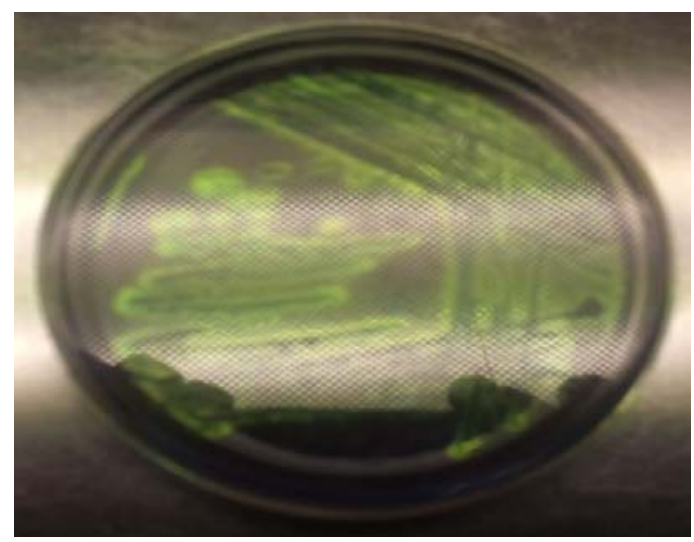

Fig. 1. Metallic sheen of E.coli on EMB agar

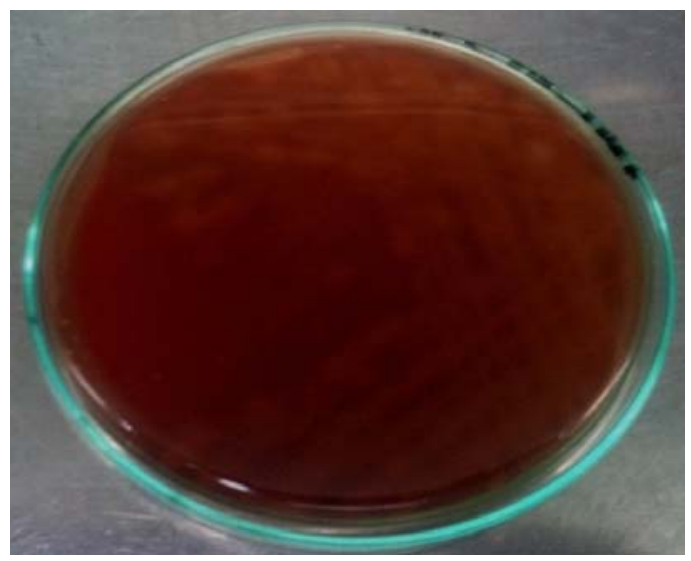

Fig. 3. Hemolysisproduced by Staphylococcus aureus on blood agar

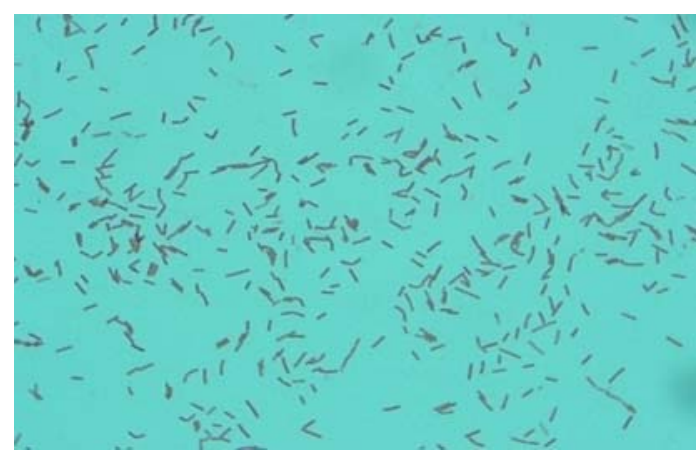

Fig. 5. Gram negative single, pair or in short chain of E.coli (Gram's stain,100X)

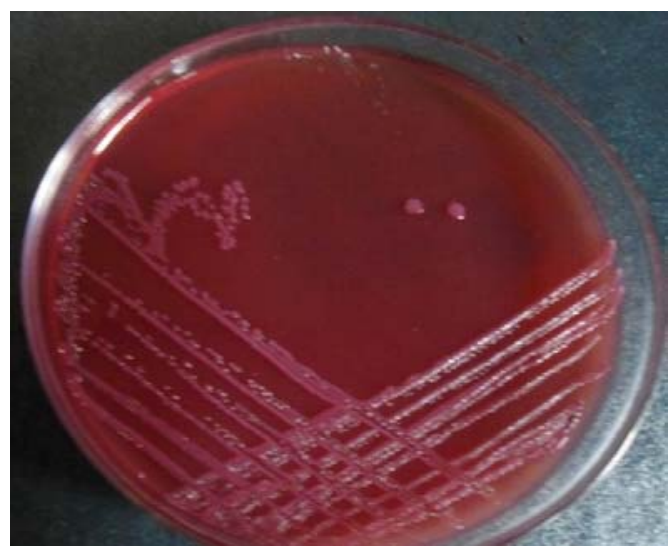

Fig. 2. Pink colour colony of E.coli on SS agar

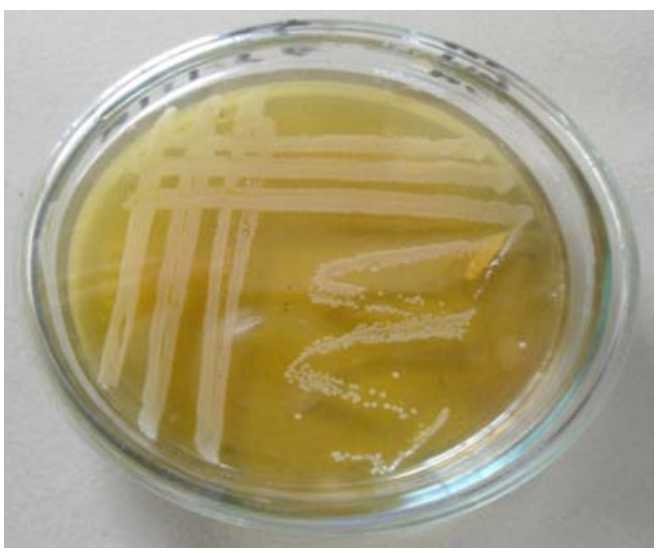

Fig. 4. Fermented whitish colony of Staphylococcus aureus in mannitol salt agar

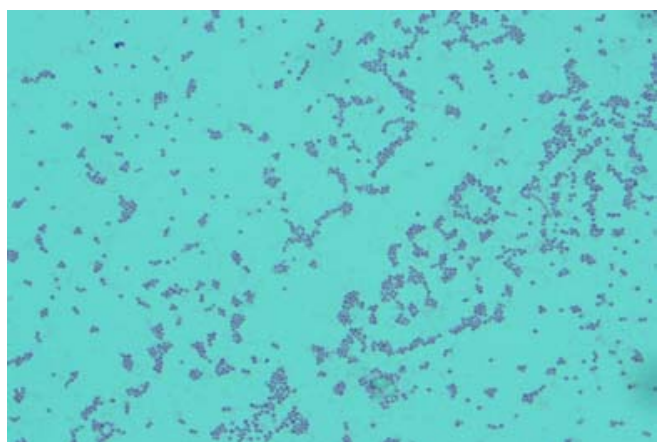

Fig. 6. Gram positive cluster form of Staphylococcus aureus (Gram's stain 100X) 


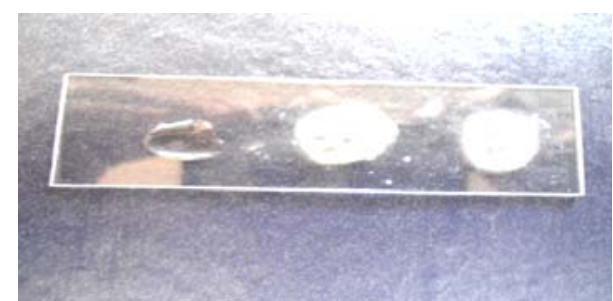

Fig. 7. Catalase positive E.coli

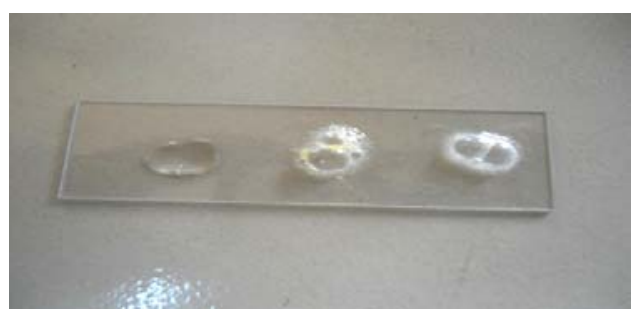

Fig. 8. Catalase positive Staphylococcus aureus

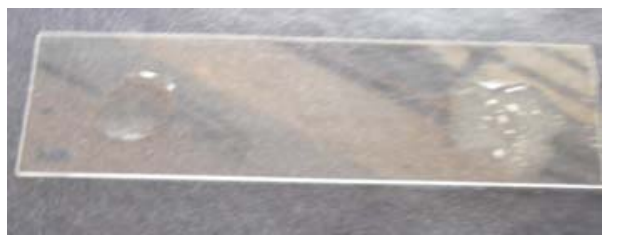

Fig. 9. Coagulase positive Staphylococcus aureus

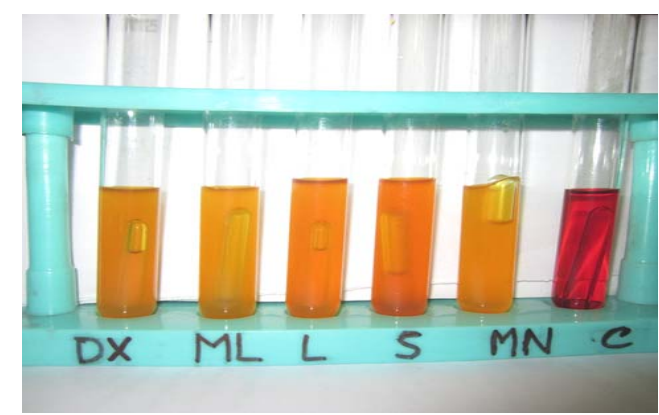

Fig. 10. Sugar fermentation tests of E.coli fermenting all sugars with acid and gas production

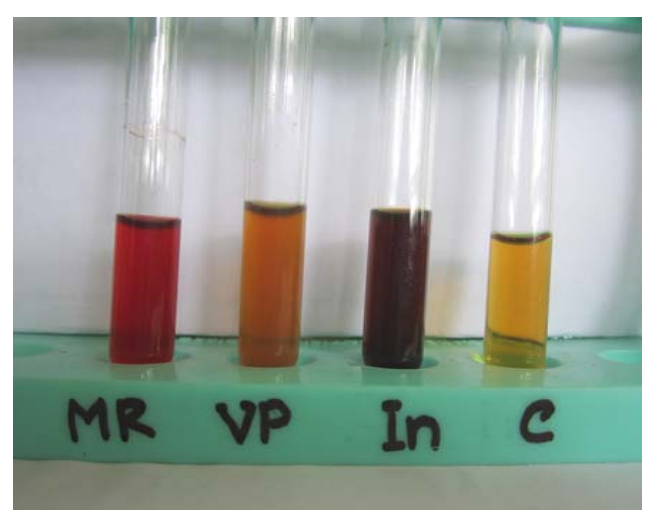

Fig. 12. Results of Methyl Red, VogesProskauer and Indole test of E. coli where MR and Indole test positive and VP test Negative

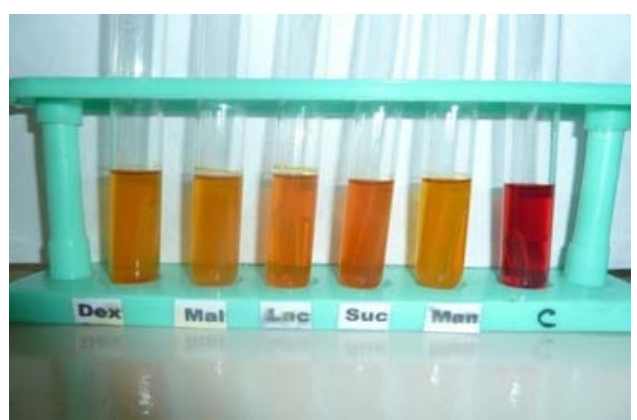

Fig. 11. Results of sugar fermentation test of Staphylococcus aureus. only acid was produced. No gas was observed in Durham's tube

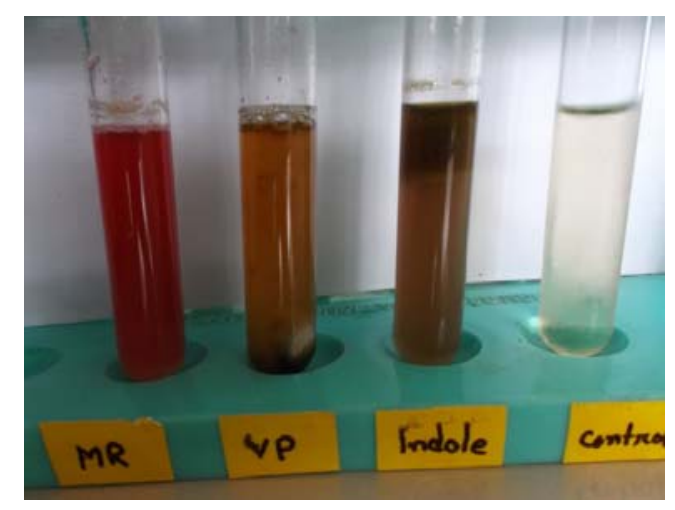

Fig.13. Results of Methyl Red, Voges-Proskauer and Indole test of Staphylococcus aureus. where MR and VP test positive and indole test negative 


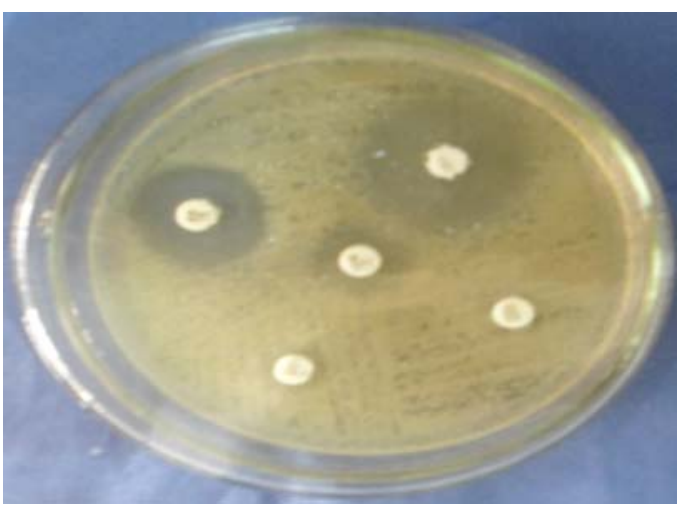

Fig. 14. Antibiotic sensitivity test of E.coli.

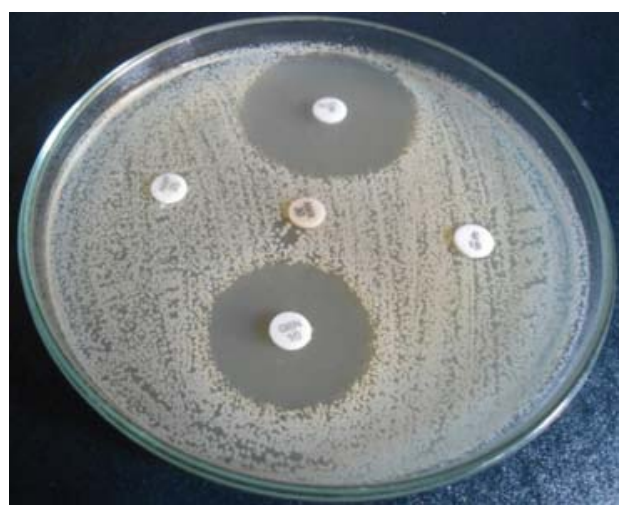

Fig. 15. Antibiotic sensitivity test of Staphylococcus aureus

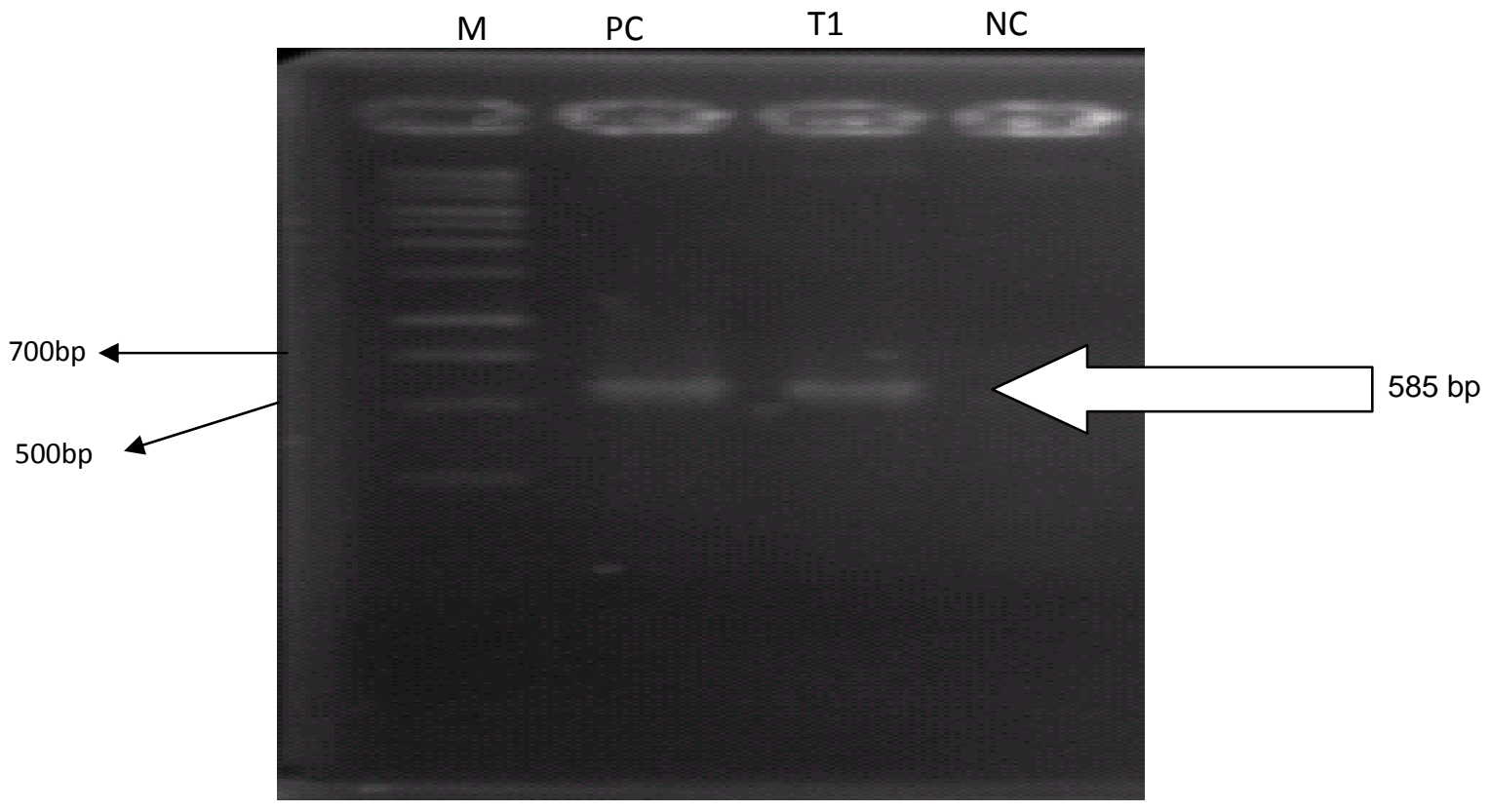

Fig. 16. Representing figure of the PCR of E.coli using the primer ECO-1 and ECO-2 targeting 16s rRNA gene.M=100bp DNA Ladder, $\mathrm{PC}=$ Positive control, $\mathrm{T} 1=$ test sample, $\mathrm{NC}=$ negative control. The presence of E.coli.was confirmed in one samples by amplification of the approximately 585bp DNA fragment 


\section{Acknowledgement}

The authors are grateful to BAURES, Bangladesh Agricultural University, Mymensingh, Bangladesh for financial support.

\section{References}

Allen, K.J., Tremaine, W.H., and Franklin, S.H. 2006. Prevalence of inflammatory airway disease in national hunt horses referred for investigation of poor athletic performance. Equine Vet. J. .(36):529-34.

Bauer, A.W., Kirby, Shrris, J.C. and Truck, M. 1966. Antibiotic susceptibility testing by a standardized single disc method. American J. Clini. Patho.,. 45: 493-496.

Blackall, P.J. 1989. The Avian Haemophili. Clin. Microbiol. Rev., 2: 270-277.

Carter, G.R. 1979. Diagnostic Procedures in Veterinary Bacteriology and Mycoplasma. 3rd edn. Charles C. Thomas Publisher U. S.A. pp. 398-417.

Cheesbrough, M. 1985. Medical laboratory manual for tropical countries. 1st edn. Vol. 2 Microbiology, English Language Book Society, London, 35: pp. 40-57.

Clinical and Laboratory Standards Institute (CLSI, formerly NCCLS). 2007. Performance standards for antimicrobial susceptibility testing. $17^{\text {th }}$ Informational Supplement document M100-S17: 1 . Wayne, Pennsyslvania. pp: 32-50.

Davis, M.S., Williams, C.C., Meinkoth, J.H. 2007. Influx of neutrophils and persistence of cytokine expression in airways of horses after performing exercise while breathing cold air. American J. Vet. Res.,. 68(2):185-9.

Davis, M.S., Malayer, J.R. and Vandeventer, L 2005. Cold weather exercise and airway cytokine expression. Journal of Applied Physiology. 98(6):2132-6.

Gerber, V., Robinson, N.E. and Luethi, S. 2003. Airway inflammation and mucus in two age groups of asymptomatic well-performing sport horses. Equine Vet. J.. 35(5) :491-5.

Hinz, K.H. and Kunjara, C. 1977. Haemophilus avium: a new species from chickens. Int. J. Systematic Bacteriology., 27 :324-329.

Jaswinder Kaur, Sharma, N.S., Kuldip Gupta and Amarjit Singh. 2004. Epidemiological studies on IC in chickens in northern India.Ind. J. Animal. Sci., 74(5): 462-465.

Kristie brookes. 2011. The History of Humans and Horses. Ezine articles.pp:12-13.

Merchant and Packer .1967. Veterinary bacteriology.Australian Vet. J.,.44:312.

Queipo-Ortun, M.I , Colmener, J.D. , Bravo, M.J. , García-Ordon, M.A. and Morata, P. 2008. Usefulness of a quantitative real-time PCR assay using serum samples to discriminate between inactive, serologically positive and active human brucellosis .Clinical Microbiology and Infection ; 14: 1128-1134.

Sameera, A., Asif, R.B., and Khushi, M. 2001. Clinico-Therapeutic Observations on an Outbreak of InfectiousCoryza. Int. J. Agri. Biol., 03(4):531-532. 